\title{
Towards a more resilient euro area
}

\author{
Esther Gordo • Ivan Kataryniuk*
}

Banco de España, Madrid, Spain

Received: 24 March 2019

Revised: 24 July 2019

Accepted: 14 September 2019

\begin{abstract}
The euro area has shown lower capacity to resist shocks than other monetary unions, such as the US. One possible determinant is the lack of risk-sharing mechanisms. In this article, we estimate the risk-sharing capacity of the Euro Area according to the Asdrubali et al. (1996) methodology. The results show that the degree of risk-sharing is low in the euro area, in particular, due to underdeveloped capital markets and the lack of a central fiscal capacity. We suggest venues of reform to increase the economic resilience of the common currency area.
\end{abstract}

Keywords: risk sharing; financial integration; fiscal policy

JEL Classification Codes: E62, F02

\section{Introduction}

In the last few years, significant steps have been taken in Europe to enhance the overall capacity to handle crisis and to make the euro area more robust. During the euro crisis, the European Stability Mechanism (ESM) was created to increase the EA's capacity to deal with debt and liquidity problems and to withstand very serious asymmetrical shocks. Further, to curtail the perverse dynamics of the feedback loop between banking and sovereign risks and the systemic consequences of institutions with strong cross-border links, significant headway has been made towards the creation of a Banking Union with the Single Supervisory Mechanism and the Single Resolution Mechanism. Finally, substantial progress has been achieved in the reduction of banking risks and non-performing loans and the coordination of economic policies at the EU level has improved significantly.

But, at the same time, there has been slow progress in some very relevant aspects of the EA governance reform. Among them, insufficient financial integration by the lack of supranational fiscal policy instruments and inadequate fiscal policy coordination, leave the EA vulnerable to economic shocks. Significant advances might be needed before the next crisis arises.

\footnotetext{
*Corresponding author. E-mail: ivan.kataryniuk@bde.es.

Citation: Gordo, E. and Kataryniuk, I. (2019) Towards a more resilient euro area, Economics and Business Letters, 8(2), 106-114.
}

DOI: $10.17811 /$ ebl.8.2.2019. 106-114 
In this article, we calculate the degree of public and private risk-sharing in the Economic and Monetary Union (EMU). In this sense, this paper is close to the literature measuring risk-sharing from an international perspective, such as Afonso and Furceri (2008), Kalemli-Ozcan et al. (2014), Furceri and Zdzienicka (2015), Alcidi and Thirion (2016) and Poncela et al. (2016). Similar to these studies, we conclude that public risk-sharing is low in the EMU, while private risk-sharing is skewed towards bank credit.

Finally, we review the rationale behind the need to develop private and public risk-sharing mechanisms in the EA and suggest venues of reform to increase the economic resilience of the common currency area.

\section{Risk sharing in EMU}

In this section, we estimate the degree of risk-sharing in the EA. In a monetary union, absent exchange rate flexibility, asymmetric shocks can cause more severe internal and external imbalances. Against this background, building fiscal buffers, eliminating price and wage rigidities and increasing the strength of risk-sharing mechanisms acquire a crucial importance to enhance the capacity to resist shocks.

When an adverse shock hits a member country of a monetary union, it may be softened if the country's resident agents obtain income (whether financial or labour) from other countries (regions) not affected by the shock (income channel). Moreover, households and firms in the affected economy may ease their consumption by resorting to their saving or to the credit market (credit channel). Logically, the greater cross-regional financial integration or labour mobility are, the greater the strength of these two channels will be. Finally, the effects of the shock may be smoothed through fiscal transfers drawn from the central or federal budget, as in the case of the United States (fiscal or budgetary channel).

\subsection{Methodology and data}

The estimates presented here follow the methodology proposed by Asdrubali et al (1996). The approach is based in the following accounting identity:

$$
G D P_{i t}=\frac{G D P_{i t}}{G N P_{i t}} \frac{G N P_{i t}}{N N P_{i t}} \frac{N N P_{i t}}{N N I_{i t}} \frac{N N I_{i t}}{C_{i t}} C_{i t}
$$

where GDP is gross domestic product, GNP gross national product, NNP net national product, NNI net national income and $\mathrm{C}$ total consumption.

With full risk-sharing through capital markets (the income channel), GDP and GNP should not commove. The difference between GNP and NNP is depreciation, which should not be related with shock smoothing, and accordingly, is treated as a non-smoothed shock. If, after accounting for income obtained abroad and depreciation, the government is able to counteract all remaining shocks with fiscal transfers, NNI and GDP will not commove. Similarly, if the residual shocks to NNI do not pass-through consumption, GDP and C will not be correlated.

Empirically, the strength of each channel can be measured using panel regressions of the following type:

$$
\begin{gathered}
\Delta G D P_{i t}-\Delta G N P_{i t}=\alpha_{1}+\beta_{1} \Delta G D P_{i t}+\varepsilon_{1 t} \\
\Delta G N P_{i t}-\Delta N N P_{i t}=\alpha_{2}+\beta_{2} \Delta G D P_{i t}+\varepsilon_{2 t} \\
\Delta N N P_{i t}-\Delta N N I_{i t}=\alpha_{3}+\beta_{3} \Delta G D P_{i t}+\varepsilon_{3 t} \\
\Delta N N I_{i t}-\Delta C_{i t}=\alpha_{4}+\beta_{4} \Delta G D P_{i t}+\varepsilon_{4 t} \\
\Delta C_{i t}=\alpha_{5}+\beta_{5} \Delta G D P_{i t}+\varepsilon_{5 t}
\end{gathered}
$$

The coefficients $\beta_{1}, \beta_{2}, \beta_{3}$ and $\beta_{4}$ approximate the percentage of risk shared through capital markets, depreciation, fiscal transfers and the credit markets, respectively. The coefficient $\beta_{5}$ 
Figure 1. Estimates of risk-sharing in the Euro Area and the United States.

RISK-SHARING MECHANISMS (a)

STRENGTH OF RISK-SHARING CHANNELS (a)

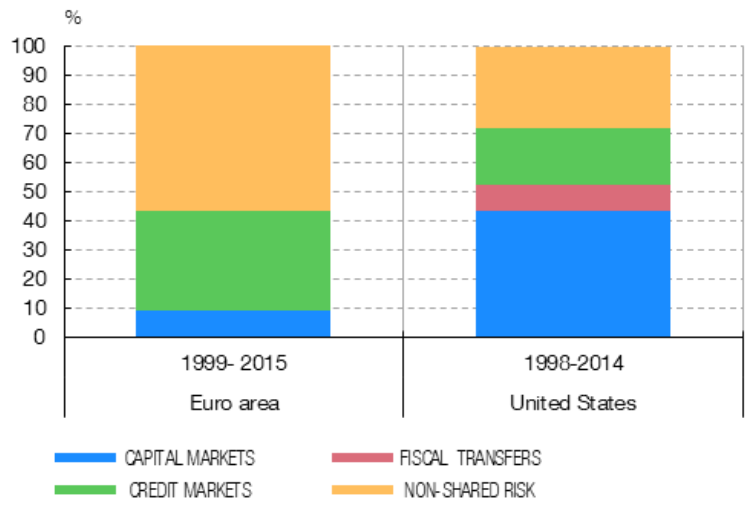

EVOLUTION OF THE STRENGTH OF RISK-SHARING CHANNELS IN THE EURO AREA (Recursive estimation)

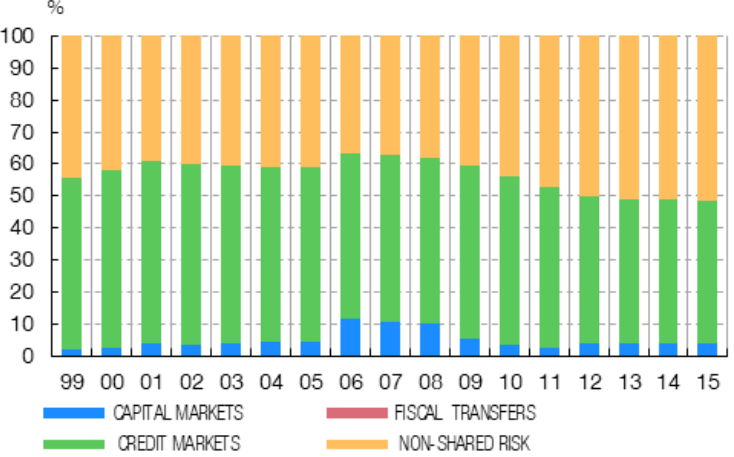

SOURCE: Banco de España.

a. Estimated following the methodology of Asdrubali et al. (1996). The chart represents the coefficients B1, B2, B4 and B5 of the equations explained in the main text which approximate risk shared through capital markets, fiscal transfers, the credit markets, and non-shared risk respectively. All estimated coedifcients are significant.

measures the percentage of non-shared risk. If $\beta_{5}$ is equal to 0 , there is full risk-sharing across the different economies.

We use the relevant data taken from national accounts, both for EA economies and states of the United States for the period 1995-2016. For the US, state national income and state disposable income are constructed using the method in Asdrubali et. al (1996). All the variables are expressed in logarithms and in deviations from the euro area or the United States average.

\subsection{Results}

Figure 1 offers estimates of the parameters of interest. The coefficients $\beta_{2}$ and $\beta_{5}$ are added in the chart as non-shared risk, and depicted in yellow. The blue bar represents risk-sharing through capital markets, or the value of coefficient $\beta_{1}$. The red bar represents the effects of fiscal transfers, or $\beta_{3}$, while the green bar is related to the credit channel, or $\beta_{4}$. The results presented are robust to different estimation procedures and they are significant at the $95 \%$ confidence levels. Non-significant coefficients, such as $\beta_{3}$ in the euro area, are not shown.

The chart shows that the strength of the risk-sharing mechanisms in the EA countries is rather limited, compared with the United States (see also Kalemli-Ozcan et al. (2014); Alcidi and Thirion (2016); Furceri and Zdzienicka (2015) and Poncela et al. (2016)). It is remarkable that the non-smoothed shock (the yellow bar) has been stable around $40 \%$ to $60 \%$, close to the estimates in Afonso and Furceri (2008).

With regard to the income channel, the degree of risk-sharing is comparatively low in Europe and, although it moved on a rising trend in the pre-crisis years as a result of the increase in financial integration, it subsequently fell, remaining at levels well below those prevalent in the United States. The justification for this may be due to the limited development of equity markets in Europe, the greater national bias still prevailing in the EA relative to the United States, and to the greater concentration of cross-border investment (within the EA itself) in a small number of Member States in the European case (Veron and Wolff (2016) and Gonçalves Raposo and Lehmann (2019)). The budgetary channel, in red, is practically non-existent in the euro area, while in the United States it is estimated that it helps soften between $10 \%$ and $20 \%$ of adverse shocks. The credit channel is thus the sole means for cushioning shocks across the EA countries, though it is not sufficient to compensate for the weakness of the other channels. That means that, on average, between $40 \%$ and $60 \%$ of an adverse shock an EA country undergoes 
translates into a decline in that country's consumption, compared with the $20 \%-30 \%$ observed in the United States.

Moreover, the strength of private channels declined during the crisis, as can be seen in Figure 1. Among other factors, that might reflect financial fragmentation processes stemming from the loss of investor confidence both in the sovereign and in the banking system of some countries, which ultimately prompted a renationalisation of financial flows.

Against this background, the development of a genuine pan-European banking system and well developed and integrated capital markets could contribute to enhance private risk-sharing mechanism and financial stability. The completion of the Banking Union and the Capital Markets Union projects should contribute decisively to this goal.

\section{Enhancing private risk-sharing mechanisms}

Substantial progress has been made to reduce excessive risk taking and increase confidence in the banking sector, which is the basis to increase cross-border financial integration. The main catalyst was the establishment of the Single Supervisory Mechanism (SSM). Currently, the European Central Bank directly supervises the significant credit institutions, representing almost $82 \%$ of the total banking assets in the euro area.

Figure 2. Indicators of financial integration.

INDICATORS OF FINANCIAL INTEGRATION

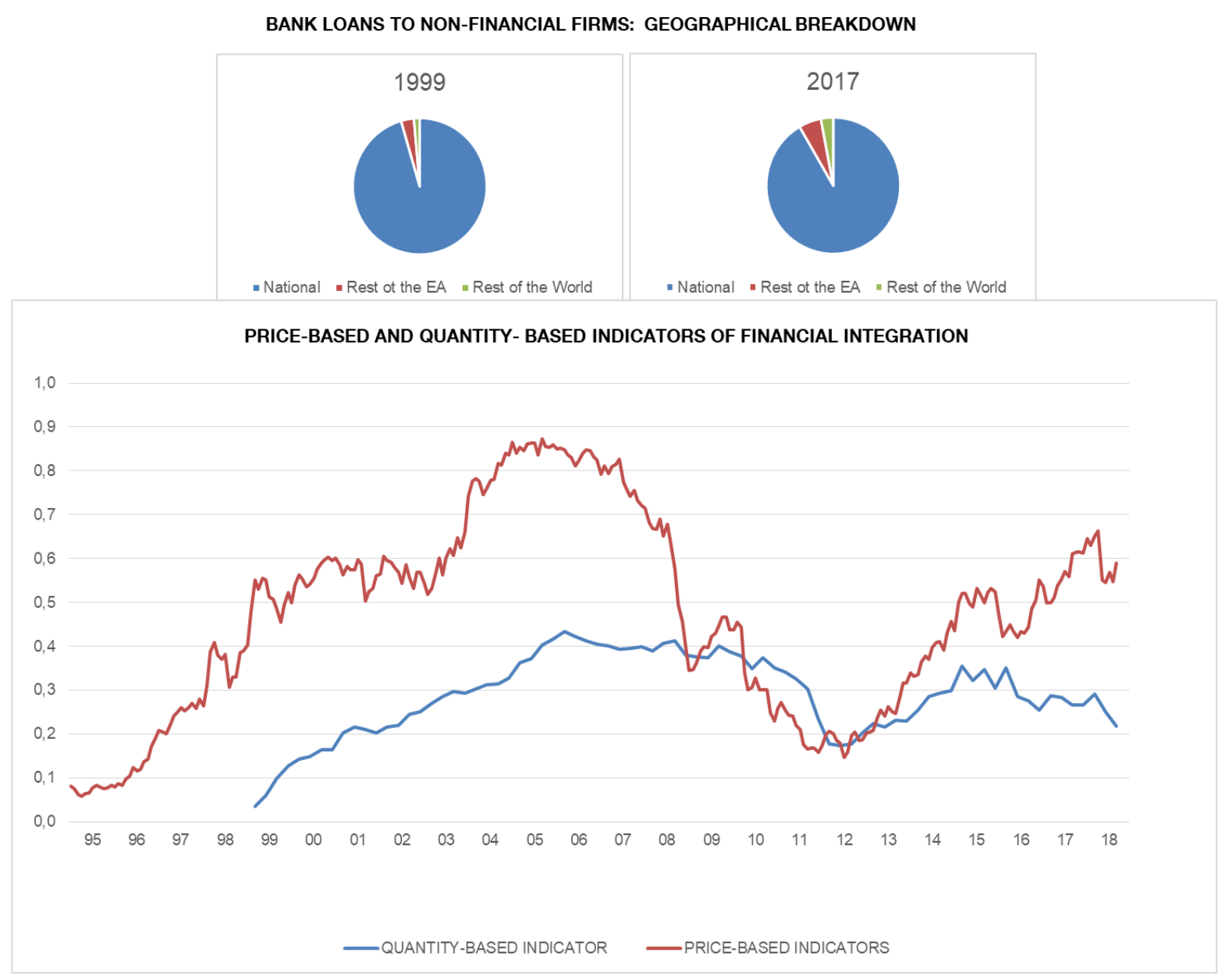

SOURCE: European Central Bank. 
Progress has also been made with the creation of the Single Resolution Mechanism that establishes homogeneous resolution criteria under the principle of minimizing taxpayer cost. The agreement achieved at the Euro Summit in December 2018 for the creation of a common financial support for the Single Resolution Fund (SRF) will ensure its capacity to face severe banking crisis without destabilizing the public finances of the affected countries.

But there are still important challenges to complete the banking union. While over the past years there has been an increase of interbank lending across the euro area countries, in contrast, retail banking integration and cross-border consolidation have remained limited. A majority of firms and households in the EA remain largely dependent on the funding provided by their domestic banking systems (see chart 2). Among other factors, this result might reflect significant differences in banking regulation across countries and national regulations that protect some of the existing banks or regional banks, preventing the creation of a true pan-European banking system.

The creation of a European Deposit Insurance System (EDIS), which would guarantee the same protection for individual depositors irrespective of their location, would reduce the banksovereign nexus and facilitate cross border banking operations. Carmasi et al. (2018) show that, with appropriate risk-based bank contributions, cross-border subsidization would be almost negligible even in the case of severe banking crisis.

In contrast to the banking union, the integration of capital markets in the EMU has experienced a lower institutional impulse. The European Commission launched the Capital Markets Union (CMU) project in 2015 with the aim to remove cross border barriers and to diversify sources of financing available for European firms and households. However, the completion of the CMU project has been slow. Only a handful of the more than thirty initiatives have been approved in 2019.

CMU can complement Banking Union by fostering alternative sources of funding, thereby reducing the high reliance of the Euro area on banking intermediation. Greater diversification through capital markets can enhance cross-border risk sharing and alleviate risks of financial fragmentation. A single or unified European supervision of capital markets, the revision of the debt financing bias existing in most taxation systems and regulatory harmonization in areas such as insolvency laws could contribute to achieve this goal.

\section{Public mechanisms: the need of a common fiscal capacity}

Market based risk sharing mechanisms cannot be sufficient to cope with severe shocks. In this regard, Fahri and Werning (2012) show that even if capital markets were fully integrated, a system based solely on private mechanisms would not be optimal, since agents do not internalize the advantages of macroeconomic stability. A supranational fiscal insurance mechanism would lead to a more efficient system.

The recent crisis has shown that some shocks are sizable enough -and may also affect several countries at the same time- that cannot be dealt just only with national fiscal buffers. A central fiscal capacity at the euro area level might increase the capacity of budgetary policy to automatically absorb adverse shocks, both aggregate and idiosyncratic, with the dual aim of softening the effects on individual countries and of safeguarding stability in the EA as a whole in extreme cases. The introduction of supranational mechanisms might also increase the scope and effectiveness of fiscal policy for the EA as a whole.

The ESM can play a key role as a shock absorber (Cimadomo et al. (2018)). However, the design of the ESM makes it ill-suited for preventing crisis, as it is conceived as a last resort instrument, which will act just in case of serious risks for financial stability. In addition, each country has a veto power over most of the financial assistance decisions.

Several alternatives exist for designing interstate public insurance mechanisms within a monetary union, requiring very different degrees of political ambition. On one hand, maximum 
proposals have been formulated, involving the creation of an economic government for the euro area, with its own extensive budget, and responsibility for a European debt agency entrusted with issuing joint debt instruments. On the other, the introduction of insurance tools in the face of cyclical shocks has been considered, in the form of contingency funds (along the lines of the US "rainy day funds"), or through unemployment insurance.

The literature highlights some of the features a mechanism of this nature should have. In particular, in keeping with the empirical evidence on the effectiveness of fiscal stimuli, any stabilising action proves all the more effective the more timely, temporary and targeted it is. Thus, the stabilisation fund should be automatically, readily and transparently activated when specific conditions were met. In this regard, most of proposals use a statistical calculation of the cyclical position, such as an estimation of the output gap, or some indicator related to the labour market, such as a threshold in the unemployment rate or the deviation in the unemployment rate from its long term average. The former has the specific disadvantage of being a nonobservable variable, subject to important revisions, especially in the most recent observations. The latter is an imperfect measure of the slack of the economy, but it is a readily available, comprehensible variable.

Furthermore, this tool should be designed in such a way as to minimize moral hazard problems, so as to retain the incentives for implementing disciplined economic policies. Accordingly, the system should be neutral in terms of its budgetary implications over an extensive time horizon, i.e. which does not entail permanent interstate transfers, unlike the current European budget, where there are net contributors and recipients. The literature has proposed several mechanisms, such as usage premiums (experience rating) or caps on cumulative net transfers or contributions to avoid permanent fiscal transfers and minimize moral hazard. However, this does not mean that the mechanism should not perform intertemporal as well as spatial stabilization functions, in the sense of funds being built up in cyclical upturns to be used in adverse circumstances.

Table 1 illustrates what would have happened had such mechanisms been in place since the creation of the EA (see also Koester and Sonderman (2018)). Specifically, we have simulated two different schemes that address concerns in terms of size and non-permanent transfers. The first one is a rainy-day fund, that uses a double condition proposed by Carnot and others (2017) requiring the unemployment rate to be above its long-term average and increasing to trigger transfers. This would contribute to minimize the risk that structural differences in labor markets could result in permanent one-way transfers.

The second scheme is designed as a complement to national unemployment insurance, as is the case in the United States, where the unemployment insurance system is the competence of the States, although central government supplements them with loans or direct transfers in adverse circumstances when there are sizable increases in unemployment (see Albrizio et al., 2017). Under this scheme, the transfers received by each particular country are determined based on the level of short-term unemployment and the average wage of the economy. The scheme is budgetary neutral across countries, in such a way that the contribution varies across countries, with the objective of restoring the country-specific balance in the fund in an average of five years.

The table presents what the funds contributed and received by the different euro area countries in their current composition would have been in cumulative terms over the 1999-2015 period. The first mechanism, with a relatively moderate size, would enable the EA to achieve a stabilizing power close to that of the federal budget transfers in the United States -measured using the methodology of Asdrubali et al (1996). The second mechanism would have a lower stabilization capacity, as it will only help to smooth shocks during a relatively short amount of time. However, as regards their potential impact on economic activity, it should be stressed that, in this case, transfers would be directly received by agents who, in principle, have a 
Table 1. A common cyclical insurance fund.

A COMMON CYCLICAL INSURANCE FUND (a) AND PAYMENTS (average 1999-2015. \% of GNP)

\begin{tabular}{|c|c|c|c|c|}
\hline & \multicolumn{2}{|c|}{ SCHEME 1 (rainy- day fund) } & \multicolumn{2}{|c|}{$\begin{array}{c}\text { SCHEME2 (unemployment } \\
\text { insurance system) }\end{array}$} \\
\hline & Contribution & Payment & Contribution & Payment \\
\hline Euro Area & 0,2 & 0,2 & 0,2 & 0,2 \\
\hline Belgium & 0,2 & 0,0 & 0,2 & 0,0 \\
\hline Germany & 0,1 & 0,2 & 0,1 & 0,2 \\
\hline Estonia & 0,8 & 0,3 & 0,8 & 0,3 \\
\hline Ireland & 0,4 & 0,3 & 0,3 & 0,2 \\
\hline Greece & 0,3 & 0,6 & 0,3 & 0,5 \\
\hline Spain & 0,4 & 0,5 & 0,3 & 0,4 \\
\hline France & 0,4 & 0,0 & 0,3 & 0,1 \\
\hline Italy & 0,1 & 0,3 & 0,2 & 0,2 \\
\hline Chipre & 0,3 & 0,2 & 0,4 & 0,1 \\
\hline Latvia & 0,5 & 0,5 & 0,5 & 0,5 \\
\hline Lithuania & 0,5 & 0,5 & 0,4 & 0,6 \\
\hline Luxemburg & 0,3 & 0,4 & 0,3 & 0,3 \\
\hline Malta & 0,2 & 0,1 & 0,1 & 0,1 \\
\hline Netherlands & 0,2 & 0,2 & 0,1 & 0,3 \\
\hline Austria & 0,2 & 0,1 & 0,1 & 0,1 \\
\hline Portugal & 0,2 & 0,3 & 0,2 & 0,2 \\
\hline Finland & 0,3 & 0,2 & 0,2 & 0,2 \\
\hline $\begin{array}{l}\text { Stabilization } \\
\text { capacity }\end{array}$ & \multicolumn{2}{|c|}{$15 \%$} & \multicolumn{2}{|c|}{$3 \%$} \\
\hline
\end{tabular}

Source: Author's calculations.

a. Scheme 1: contributions are 1\% of GDP. Trasfers are calculated as $1 \%$ of GDP per point of increment of the unemployment rate. Scheme 2: Transfers are calculated taking into account the short term unemployment level and the average wage of the economy (replacement rate $=0.5$ ); contributions vary across countries an across time to ensure non permanent transfers and the financial equilibrium of the system.

high propensity to spend, as is the case of the unemployed or individuals subject to credit or liquidity constraints, meaning that their economic impact might prove significant. In the case of the United States, the smoothing capacity during crisis is sizable, whereas the effect in normal times is negligible (Albrizio et al., 2017). When monetary policy is constrained by the zero lower bound fiscal multipliers might be even higher.

As can be seen in Figure 3(a), these schemes could contribute to enhance fiscal stabilizers at the EA level. Figures 3(b) and 3(c) illustrates for Spain and Germany that both countries would have paid transfers to the scheme during the boom years before 2008, and both would have received transfers after the crisis, when unemployment registered a significant increase.

\section{Conclusions}

Individual countries in the Euro Area experience lower capacity to resist external shocks than US states. One possible determinant is the lack of risk-sharing mechanisms. During the crisis, the overreliance on bank financing resulted in a procyclical behavior of risk smoothing, as restrictions to credit hit more in the most affected countries. Some institutional arrangements, such as the advances in the Banking Union and the creation of the ESM, are now in place, although much is needed in terms of financial integration and fiscal coordination to achieve the risk-sharing capacity of more complete currency unions, such as the United States 
Figure 3. Net transfers paid (-) and received (+) (\% of GDP).

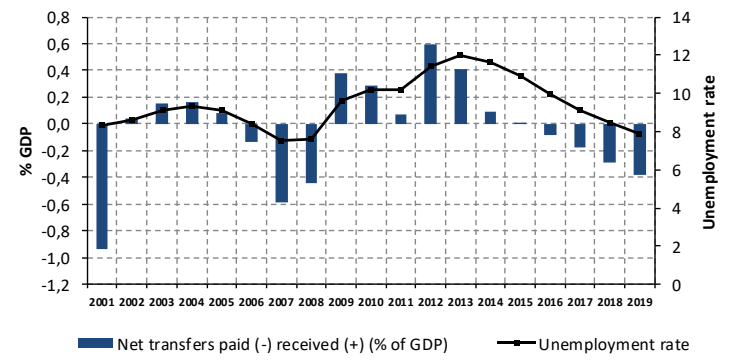

(a) EA-19

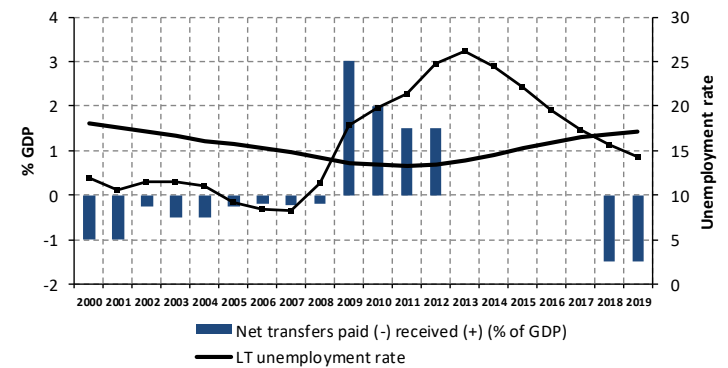

(b) ES

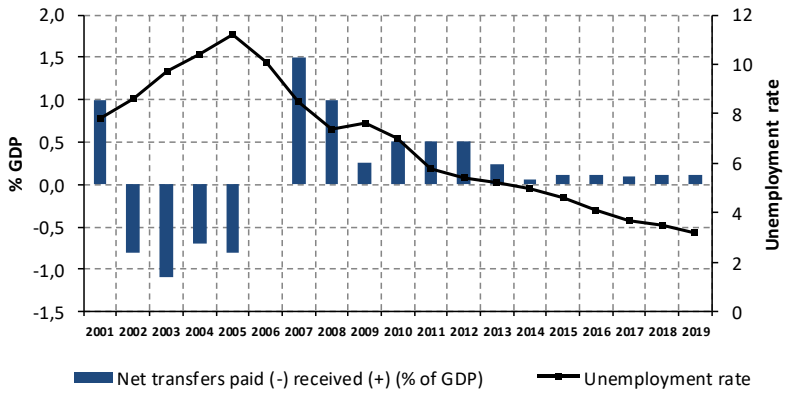

(c) $\mathrm{DE}$

Source. Author's calculations.

Higher integration of capital markets in the European Union and the development of a European banking market might contribute to more private risk-sharing through the income channel and the credit channel, respectively. In this respect, the completion of the Banking Union, as long as a greater impulse in the Capital Markets Union, might increase consumption smoothing by developing cross-border markets for equities and banks. In the case of the public risk-sharing channel, a fiscal stabilization mechanism of a moderate size can substantially increase risk-sharing.

The article focuses on mechanisms of mutual insurance, but other institutional reforms, such as the improvement of fiscal rules, can increase the resilience of economies and generate confidence to external investors that enhance the risk-sharing capacity of mutual mechanisms.

\section{Acknowledgements}

This paper is the sole responsibility of the authors and the views represented here do not necessarily reflect those of the Banco de España or the Eurosystem.

\section{References}

Afonso, A., and Furceri, D. (2008) EMU enlargement, stabilization costs and insurance mechanisms, Journal of International Money and Finance, 27(2), 169-187.

Albrizio, S., Berganza, J. C., and Kataryniuk, I. (2017) Federal unemployment insurance in the United States, Banco de España, article 12/17.

Alcidi, C., and Thirion, G. (2016) Assessing the euro area's shock-absorption capacity: risk sharing, consumption smoothing and fiscal policy, CEPS Special Report, 146.

Asdrubali, P., Sorensen, B.E., and Yosha O. (1996) Channels of Interstate Risk Sharing: United States 1963-1990, Quarterly Journal of Economics, 111, 1081-1110.

Carnot, N., Kizior, M., and Mourre G. (2017) Fiscal stabilisation in the Euro-Area: A simulation exercise, ULB--Universite Libre de Bruxelles, No. 17-025. 
Carmassi, J., Dobkowitz, S., Evrard, J., Parisi, L., Silva, A. F., and Wedow, M. (2018) Completing the Banking Union with a European Deposit Insurance Scheme: who is afraid of cross-subsidisation?, ECB occasional paper, 208.

Cimadomo, J., Furtuna, O., and Giuliodori, M. (2018) Private and public risk sharing in the euro area, ECB Working Paper, 2148

Farhi, E., and Werning, I. (2017) Fiscal Unions. American Economic Review, American Economic Association, 107 (12), 3788-3834, December.

Furceri, D., and Zdzienicka, A. (2013) The euro area crisis: need for a supranational fiscal risk sharing mechanism?, International Monetary Fund, No. 13-198.

Gonçalves Raposo, I., and Lehmann, A. (2019) Equity finance and capital market integration in Europe, Bruegel Policy Contribution, 3.

Kalemli-Ozcan, S., Luttini, E., and Sørensen, B. (2014) Debt Crises and Risk-Sharing: The Role of Markets versus Sovereigns. Scandinavian Journal of Economics, 116(1), 253-276.

Koester, G. B., and Sondermann D. (2018) A Euro Area Macroeconomic Stabilisation Function: Assessing Options in View of Their Redistribution and Stabilisation Properties, ECB Occasional Paper, No. 216.

Poncela, P., Pericoli, F., Manca, A. R., and Nardo, M. (2016) Risk sharing in Europe, European Commission JRC Science for Policy Report, 104621.

Véron N., and Wolff, G. B. (2016) Capital Markets Union: A Vision for the Long Term, Journal of Financial Regulation, 2(1), 130-153. 